\title{
MAPPING INJURIES IN TRAFFIC ACCIDENT VICTIMS: A LITERATURE REVIEW
}

\author{
Ana Maria Calil ${ }^{1}$ \\ Elias Aissar Sallum ${ }^{2}$ \\ Cristiane de Alencar Domingues ${ }^{3}$ \\ Lilia de Souza Nogueira ${ }^{3}$
}

Calil AM, Sallum EA, Domingues CA, Nogueira LS. Mapping injuries in traffic accident victims: a literature review. Rev Latino-am Enfermagem 2009 janeiro-fevereiro; 17(1):120-125.

The objective of this study was to identify the body regions most affected in traffic accident victims and to map the trauma and severity of the lesions. A systematic literature review using key words related to traffic accidents, transportation accidents, wounds and injuries found a total of 248 articles. The electronic bases LILACS, MEDLINE, and PAHO were surveyed between the years 1990 and December 2006. This review emphasized a series of conclusive studies about the most frequent body regions involved and the major injuries occurring in these situations. It also indicated information gaps in the Brazilian literature. We believe that these findings are valuable for pre-hospital and intra-hospital teams and point the way to new investigations.

DESCRIPTORS: accidents, traffic; wounds and injuries; epidemiology

\section{IDENTIFICACIÓN DE LESIONES EN VÍCTIMAS DE ACCIDENTES DE TRÁNSITO: REVISIÓN SISTEMÁTICA DE LA LITERATURA}

El objetivo del estudio fue identificar las regiones corpóreas más afectadas en víctimas de accidentes de transporte e identificar la gravedad de las lesiones y del trauma. Fue realizada una revisión sistemática de la literatura, utilizándose descriptores relacionados a los accidentes de tránsito, accidentes de transporte, heridas y lesiones, totalizando 248 artículos. Las bases electrónicas investigadas fueron LILACS, MEDLINE y PAHO, entre 1990 y diciembre de 2006. Esta revisión destacó una serie de estudios conclusivos sobre las regiones corpóreas más frecuentes y aquellas de mayor gravedad afectadas en esos eventos y apuntó lagunas de conocimiento en la literatura nacional. Pensamos que lo encontrado puede ser de gran importancia para los equipos en los escenarios de prehospitalario e intrahospitalario y apuntan caminos en dirección de nuevas investigaciones.

DESCRIPTORES: accidentes de tránsito; heridas y lesiones; epidemiología

\section{MAPEAMENTO DAS LESÕES EM VÍTIMAS DE ACIDENTES DE TRÂNSITO: REVISÃO SISTEMÁTICA DA LITERATURA}

O objetivo do estudo foi identificar as regiões corpóreas mais atingidas em vítimas de acidentes de transporte e mapear a gravidade das lesões e do trauma. Foi realizada revisão sistemática da literatura, utilizando-se descritores relacionados aos acidentes de trânsito, acidentes de transporte, ferimentos e lesões, totalizando 248 artigos. As bases eletrônicas pesquisadas foram LILACS, MEDLINE e PAHO, entre 1990 e dezembro de 2006. Essa revisão destacou uma série de estudos conclusivos sobre as regiões corpóreas mais freqüentes e aquelas de maior gravidade atingidas nesses eventos e apontou lacunas de conhecimento na literatura nacional. Acredita-se que esses achados possam ser de grande valia para as equipes nos cenários de pré-hospitalar e intra-hospitalar e apontem caminhos na direção de novas pesquisas.

DESCRITORES: acidentes de trânsito; ferimentos e lesões; epidemiologia

${ }^{1}$ RN, Ph.D. in Nursing, Collaborating Professor at Centro Universitário São Camilo, Brazil, e-mail: easallum.fnr@terra.com.br; ${ }^{2}$ Physician, Ph.D. in Medicine, Assistant Physician at Hospital das Clínicas da Faculdade de Medicina da Universidade de São Paulo, São Paulo, Brazil, e-mail: easallum.fnr@terra.com.br; ${ }^{3}$ RN, M.Sc. in Nursing, e-mail: crismingues@usp.br, lilianogueira@usp.br. 


\section{INTRODUCTION}

External causes are among the main causes of morbidity and mortality in the world, and the number of deaths as a result of traffic accidents in 2005 in Brazil was 35,763, which corresponds to an average of 98 deaths per day ${ }^{(1)}$.

As to the victims that were hospitalized, the numbers are alarming. Almost 120,000 hospitalizations occurred in 2005, which represents a rate of 64 hospitalizations for every 100,000 inhabitants ${ }^{(1)}$ by the Sistema Único de Saúde (SUS) the Brazilian national public health system. The number of accidents with victims in 2005 was 383,371, with a total 513,510 victims, which translates to, on average, 1406 accidents/day and 1369 victims/day (1.30 victim per accident) $)^{(1)}$.

Reports by the World Health Organization about the Mortality Database, referring to the period from 1990 to 2003, revealed that external causes were responsible for about $12 \%$ of the deaths in the world, which corresponds to, approximately, 8 million deaths per year, and traffic accidents were responsible for a large proportion of these deaths (3.9 million) ${ }^{(2)}$.

Early in this decade, some 20 to 50 million people in the world became totally or partially incapacitated due to injuries caused by traffic accidents. Injured and trauma victims took $10 \%$ of all hospital beds that year ${ }^{(3)}$.

In Latin America, the approximate cost associated with incapacities and death due to these events was 18.9 billion dollars; in highly motorized countries, it was 453.3 billion $^{(3)}$. In Brazil, in 2004, traffic accidents caused a total of 117,155 hospitalizations. This means that $15.5 \%$ of hospitalizations were due to injuries, which shows the impact of these injuries ${ }^{(4)}$.

A large number of patients remain for weeks, months, or even years in rehabilitation programs and physiotherapy, losing salaries and their jobs due to these events. This points to the economic-social dimension of the problem ${ }^{(5)}$.

The inquietudes in view of this sad situation, showing external causes as the third highest cause of unclear deaths, as well as the urgency and necessity of measures to help better understand the consequences of trauma and implement assistance programs to individuals involved in these occurrences, led to the present inquiry about whether there are similarities in the injuries of traffic accident victims.
To organize these possibilities and inquiries, systematic reviews can be useful in their identification. Within this context, the purpose of this study was to identify the existence of specific and common characteristic between the body regions and injuries in traffic accident victims, considering their frequency and severity.

\section{METHODOLOGY}

This is a systematic review. Systematic reviews aim to synthesize the knowledge in a certain area by formulating a question and then identifying, selecting, and evaluating studies, critically seeking a consensus about some practice or concept in which the available knowledge is insufficient or controversial $^{(6)}$. The research question was: what body regions are most frequently and most severely injured in traffic accident victims? With this question, the task was to identify similarities and differences in the frequency and severity of traffic accident victim injuries.

The search for articles included a survey in electronic databases, and a manual search of statements in the initially identified publications. The electronic databases included in the survey were LILACS (Latin-American and Caribbean Health Sciences), COMPREHENSIVE MEDLINE (Medical Literature end Retrieval System on Line), and PAHO (Pan American Health Organization Database). In MEDLINE, only English keywords were used, while in the others, the keywords used were in Portuguese, Spanish, and English. The research period was between 1990 and December 2006.

The article search was performed using descriptors standardized by the Medical Subject Heading (MESH) and Descritores em Ciências da Saúde - Health Science Descriptors (DeCS), as follows: traffic accidents, transportation accidents, wounds and injuries, trauma severity indices, and epidemiology. To refine the search, the terms classification, prevention, control, and evaluation were added to these combinations. In the end, there were 1236 combinations between the descriptors to obtain a maximum possible number of references.

The titles and abstracts of each article identified in the electronic search were reviewed. Where possible, the studies that seemed to meet the inclusion criteria were obtained in full. A list was made, containing the articles to be included in the study. 
The inclusion criteria were study articles published in periodicals about traffic or transportation accidents (pedestrians, motorcycle, or automobile), containing data about the characterization of the frequency, injury and/or trauma severity, or that addressed the affected body regions. The period considered in the survey was from 1990 to December 2006, and studies could be published in Portuguese, Spanish, and English.

Studies were chosen if they identified the injury severity using the Abbreviated Injury Scale (AIS) index, of anatomical basis, presented as a manual in which hundreds of injuries are listed according to their type, location, and severity, composing over 1300 injury descriptions. The severity of each injury ranges from AIS1 to AIS6, of which scores were defined by trauma specialists according to life risk, i.e. score 1 indicates light injury and 6 indicates maximum severity of injury ${ }^{(7)}$.

Trauma severity was observed using the New Injury Severity Score (NISS). The body regions, according to the instructions in these severity manuals, are divided into six categories: head/neck, face, thorax, abdomen or pelvic contents, upper/ lower limbs, and external surface.

Studies using the Maximum Abbreviated Injury Scale (MAIS), which refers to the major injury identified by the AIS in a patient, were also included.

Reading was limited to articles that addressed injury severity, trauma severity, and analyzed the body regions or common aspects of these variables.

\section{RESULTS}

In the MEDLINE database, considering the period between 1990 and 2006, 2743 articles were located and 178 were included. Of the total of 208 articles found in the LILACS database, 52 were included, and only 18 of the 150 articles found in the PAHO database were included. In total, 248 articles met the inclusion criteria.

The main reasons for excluding articles were: it was an update article, case study, or did not describe the injuries in terms of their severity and frequency or affected body region. The manual search did not add any new articles. Some articles were included in more than one database and, when this occurred, the oldest article was included.
Of the 248 analyzed articles, 226 were crosssectional studies using a quantitative approach, 18 were cohort studies, and 4 were systematic reviews.

It is noted that, among the selected studies, 120 addressed injury severity, 55 also included trauma severity, and only 73 addressed the most affected body regions.

The survey found original studies from five continents, highlighting North-American, Australian, and Asian publications. Regarding Brazil, 34 studies were located.

As to the patients' characteristics, the studies were unanimous in pointing out men aged 40 years or less as the most common victims, especially those aged 19 to 29 years. It was observed that children and elderly individuals comprised the majority of those involved in pedestrian-vs-auto accidents.

As to the type of victim, i.e., motorcycle user, automobile user, and pedestrian (struck by vehicle), there was a variation in the findings according to the period the study was performed (before 1999) and the country or location where the event took place. In Asian countries, motorcycle and bicycle accidents prevail in a uniform manner over the analyzed years, due to the large number of these used as the main mode of transportation.

In terms of auto and pedestrian accidents, auto injury patients were found in greater numbers. This finding was expected since there can be more passengers in a vehicle, and also because of the great number of cars in countries like the United States of America (USA), Canada and Brazil.

Adopting preventive measures, such as increasing the crossing time for pedestrians in streets and avenues in European and North-American countries, was identified as an effective measure to reduce pedestrian-vs-auto accidents in some countries. Nevertheless, the type of victim was found with less homogeneity among the studies.

Specifically concerning Brazil, most studies reported automobile users as the most frequent victims until the year 2000, when motorcycle users became the most frequent victims of injury. It should be emphasized that accidents involving being struck by an automobile are generally regarded as the most lethal of accidents.

As to the most frequently injured body region, upper and lower limbs are highlighted, followed by the head region. The thorax region, external surface and face alternated in the studies in terms of 
frequency, and the thorax, abdomen, and limbs in terms of severity.

As to severity, there is no doubt it can be affirmed that injuries to the head region, referred to as craniocerebral trauma (CCT), rank first in terms of injury severity. It is important to emphasize that numerous studies report the head region as the one with most injuries IS $\geq 4$.

In terms of trauma severity, most studies state that between $58 \%$ and $60 \%$ of people involved in traffic accidents have trauma severity $\leq 16$, considered to be moderate to light, and around $35 \%$ to $40 \%$ have serious or life-threatening trauma.

\section{DISCUSSION}

A great number of patients are transported to the emergency ward due to traffic accident injuries. These cases are a daily challenge for the teams working in pre and intra-hospital settings, especially due to the severity of the injuries and to the time it takes to reach the hospital and forward patients to surgery ${ }^{(8)}$.

The variety and possible severity of the clinical conditions that occur in a trauma make it essential to reach a fast and precise diagnosis of the nature of the injuries. The differentiation between the injuries and the severity potential that risk life (CCT, thoracic and abdominal injuries) is critical in order to start treatment immediately and discharge or admit patients to hospital ${ }^{(8)}$.

Although the clinical presentation of patients with traffic accident injuries can vary immensely, especially because of the organic responses from shock and changes in hemodynamic and respiratory parameters, about $50 \%$ of patients present limb injuries and about $40 \%$ present more than one injury ${ }^{(3,9)}$.

A national study analyzed the distribution of injuries per body region in traffic accident victims, and found that motorcycle users had a significantly higher number of injuries to the upper limbs, lower limbs, and pelvis compared to other victims, while there were more head/neck and face injuries in run-over and automobile accidents ${ }^{(10)}$

Another study verified the injuries in 3594 hospital admissions in 28 North American trauma centers and identified that the most affected body regions were the upper limbs, lower limbs, and pelvis in $51 \%$ of cases $^{(11)}$.
The analysis regarding the location of injuries in 6099 victims of this event in the South of Brazil identified that the most affected body regions were the lower and upper limbs (69.7\%), the head (49.6\%), and the thorax $(19.9 \%)^{(12)}$.

The distribution found in the analyzed studies often shows the upper/lower limbs and pelvis, and head/neck regions as the two most affected body regions in traffic accidents, with variations for the other affected regions.

Isolated upper or lower limb injuries are rarely fatal, but often require reparative and corrective surgeries and amputations, which have a direct influence on the quality of life of patients and their family.

Only one national study evaluated the most common injuries in automobile users, motorcycle users and pedestrians, using the proposed severity indices, and found that the most common injuries for the limb region were: wrist contusion, torsion of the clavicle, elbow contusion, finger fracture (AIS=1), lower and upper limb bone fracture, elbow luxation, tendon laceration, hand laceration $($ AIS $=2)$, multifragmentary pelvis fracture, femur fracture, knee joint rupture, femoral and axillary artery laceration $(\mathrm{AIS}=3)$, and traumatic amputation above the knee $(A I S=4)$. Injuries with greater severity, like AIS $=5$ and $\mathrm{AIS}=6$, were not identified.

As to the most severely affected body region, the head/neck had a percentage a lot higher than the other regions; these injuries scored AISe"4 in most studies. This finding is extremely important, due to the high prognostic value determined by injuries in this body segment ${ }^{(13)}$.

CCT in traffic accident victims is the most common isolated injury in severe and fatal cases, and it causes the highest number of sequelae, incapacities and deficiencies. The overall analysis of the studies highlights pedestrians as the victim in cases that are most likely to evolve to death when this body segment is injured ${ }^{(5,10)}$.

The most common head injuries, according to the severity classification, were: post-CCE amnesia, post-trauma headache, and cervical spine torsion (AIS $=1)$, simple skull fracture, cervical spine luxation $($ AIS $=2)$, cerebral contusion $(\operatorname{AIS}=3)$, intracranial hematoma, depressed skull base fracture $(A I S=4)$. Injuries of greater severity (AIS $=5$ and AIS $=6$ ) were not identified $^{(10)}$. 
The thoracic region appears as the second most severely injured region in most studies. Recent studies about trauma report it is a body segment with high risk to patients, since it contains organs like the heart and lungs ${ }^{(10)}$. The injuries most frequently found in this body segment were: rib fracture $(A I S=2)$, lung, hemo or pneumothorax contusion (AIS=3), and bilateral hemopneumothorax, hemopneumomediastinum (AIS $=4$ ). One pedestrian had an injury of severity $=5$ (bronchi rupture) and another pedestrian had a maximum severity injury

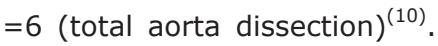

As to the abdomen, the main injuries found were: stomach laceration, liver contusion, spleen contusion $(A I S=2)$, retroperitoneum hematoma, important contusion involving liver/spleen veins $($ AIS $=3)$, important liver laceration (AIS=4). There was one automobile user with an injury AIS $=5$ (complex liver rupture) $^{(10)}$.

As to the face region, commonly injured in all kinds of traffic accidents, the following injuries are highlighted: nose and tooth fracture (AIS=1), cheekbone or mandible fracture, cornea laceration $($ AIS $=2)$, and optic nerve laceration and Lefort II fracture (AIS $=3$ ). On the external surface, there are mostly contusions, abrasions, and superficial lacerations that do not have a severity index above AIS $=2$.

It should be emphasized that victims with injuries equal to or above 5 died and, of the total studied patients (220), 45 died, of which 30 (66.6\%) were pedestrians. This type of victim had more CCE $(48.5 \%)$ than the others ${ }^{(10)}$. These findings are in agreement with the literature ${ }^{(3,8-9)}$.

Approximately $40 \%$ of the injuries are multiple and occur in the following body regions: head/ neck, face, abdomen/pelvic content, and more than $50 \%$ occur on upper limbs, lower limbs and pelvis. Traffic accident victims are often characterized as polytrauma patients or as having multiple injuries in the same body segment. This situation worsens the prognosis and, therefore, requires emergency evaluation from the surgery teams ${ }^{(14)}$.

It is observed that, in most traffic accidents, the severity rates equal to or below 15 correspond to around $58 \%-60 \%$ of all events, but an important percentage of traffic accident victims present trauma severity ISS $\geq 16^{(15-17)}$.

Studies involving trauma severity highlight pedestrians as the most frequent fatal victims. This situation is easy to understand because it is a case of hundreds of kilos of steel against a far smaller number of kilos of weight, and it is the most mortal type of traffic accident in the world ${ }^{(10,15)}$

There is a difference in Brazil in terms of the type of accidents, with collisions prevailing in approximately $50 \%$ of cases. The proportion of events varies considerably; for instance, pedestrian-vsautomobile accidents in Roraima were responsible for $7.1 \%$ of all accidents, while they account for $39.5 \%$ and $43.3 \%$ in Rio de Janeiro and Amazonas, respectively ${ }^{(1)}$.

This distinct panorama found in the country should serve as a guide for preventive and educational measures in each region.

It is important to emphasize that the mortality rate for motorcycle users showed the highest increase from 1996 to 2005: 540\%, rising from 0.5 to 3.2 per 100,000 inhabitants. This rapid climb can be understood due to the increase in the current fleet (65.3\% between 2001 and 2005), whereas the automobile fleet increased from 142.5 to 165.5 (a $16.1 \%$ increase $)^{(1,13)}$.

After this broad review, points of agreement and disagreement were found regarding the universe of traffic accident victims. It was found that the national literature presents a solid body of knowledge about the epidemiology of external causes in terms of traffic accidents. Nevertheless, there is a scarcity of studies that describe the injuries affecting these victims with greater detail.

The knowledge of this traffic accident reality, and facts regarding the most frequently affected body regions, as well as their severity, could contribute to implement, set up and develop assistance programs for individuals involved in these accidents, in addition to providing an analysis of the situation and appoint the need to perform other studies that would serve as a reference for the teams working in pre- and intrahospital environment, to establish conducts, assign priority of care, develop protocols, direct human/ material resources, and plan care.

\section{CONCLUSIONS}

The analysis of the studies showed that the most commonly affected body regions in traffic accident victims are upper/lower limbs, followed by the head/neck region. In terms of severity, the head/ neck region is highlighted in studies related to severity 
and mortality. It is important to emphasize that numerous studies report the head region as the area most affected by injuries with AIS equal to or above 4 . Regarding the third most affected body region, studies differ in identifying the face, thorax, and external surface regions; in terms of severity, the thoracic region is highlighted as second. Several studies emphasize that health teams should double their attention in accidents in which the thorax and abdomen regions have been injured or, due to the trauma mechanism, present potential for injuries in these body segments, because of their relation to serious cases of hemorrhage and respiratory arrest.
As to the type of victim, there was no homogeneity among the studies, varying in terms of the location of the accident (country) and the analyzed period.

In Brazil, accidents and mortality involving motorcyclists increased significantly as of 1999, although the literature reports pedestrians as the most vulnerable victims. Studies that analyze traffic accident injury frequency, type and particularities are scarce in our environment or extremely circumscribed to a location/municipality, and most choose to focus on only one type of victim, which makes comparisons difficult. Further broader (multicentric) studies should be encouraged.

\section{REFERENCES}

1. Mello Jorge MHP, Koizumi MS. Acidentes de trânsito no Brasil: um atlas de sua distribuição. São Paulo (SP): ABRAMET; 2007.

2. Organização Mundial de Saúde [homepage na Internet]. Base de Dados de Mortalidade, 2005 [Acesso em 2006 setembro 19]. Disponível em: http://www.WHO.int/WHOSIS. 3. Souza ER, Minayo MCS, Franco LG. Avaliação do processo de implantação e implementação do Programa de Redução da Morbimortalidade por Acidentes de Trânsito. Epidemiologia e Serviços de Saúde 2007 janeiro-março; 16(1):19-31.

4. Ministério da Saúde [homepage na Internet] Brasília: Ministério da Saúde [Acesso em 2007 outubro 13]. Informações de Saúde. Disponível em http:// w3. datasus.gov.br/ datasus/datasus.php.

5. Boto GR, Gómez PA, De La Cruz, Lobato RR. Severe head injury and the risk of early death. J. Neurol. Neurosurg. Psychiatry 2006 September; 77(9): 1054-9.

6. Atallah AN, Castro AA. Revisão sistemática da literatura e metanálise: a melhor forma de evidência para tomada de decisão em saúde e a maneira mais rápida de atualização terapêutica [Acesso em 2005 maio 15]. Disponível em: http:/ /www.epm.br/cochrane.

7. Association for the Advancement of Automotive Medice AAAM. Abbreviated Injury Scale (AIS): 2005. Des Plaines, Illions; 2005.

8. American College of Surgeons-ACS. Committee on Trauma . Suporte avançado de vida no trauma-SAVT: Programa para médicos. Tradução do Programa ATLS. São Paulo; 2004.
9. Henriksson E, Ostron M, Eriksson A. Preventability of vehicle- related fatalities. Accidental Anal Previous 2001 $33(4): 467-75$.

10. Calil AM. Natureza da lesão e gravidade do trauma segundo qualidade das vítimas de acidentes de trânsito de veículo a motor. [dissertação]. São Paulo (SP): Escola de Enfermagem da Universidade de São Paulo; 1997.

11. Gennarelli TA, Champion HR, Copes WS, Sacco WJ . Comparison of mortality, morbidity and severity of 58.713 head injury patients with 114.447 patients with extracranial injuries. J Trauma 1994 December; 37(6): 962-8.

12. Ott EA, Favaretto ALF, Neto AFPR, Zechin, JG, Bordin, R. Acidentes de trânsito em área metropolitana da região sul do Brasil: caracterização das vítimas e das lesões. Rev. Saúde Pública 1993 outubro; 27(5): 350-6.

13. Oliveira NLB. Fatores associados ao risco de lesões e óbito de motociclistas envolvidos em ocorrências de trânsito. [tese]. São Paulo (SP): Escola de Enfermagem da Universidade de São Paulo USP ; 2008.

14. Vanlar W, Yannis G. Perception of road accident causes. Accidental Anal Previous 2006; 38 (1):17-25.

15. Liberatti CL, Andrade SM, Soares DA. The new Brazilian traffic code and some characteristics of victims in southern Brazil. Inj Prev 2001 September; 7(3):190-3.

16. Elliot MA, Baughan CJ, Sexton BF. Errors and violations in relation to motorcyclists' crash risk. Accidental Anal Previous 2007; 39 (3): 491-9.

17. Calil AM, Pimenta CAM . Relação entre o padrão de analgesia e região corpórea em pacientes de trauma. Rev Gauch Enferm 2008; 29 (1). No prelo. 